\title{
Ruderal succession starting at different seasons
}

\author{
REINHARD BORNKAMM
}

\author{
Institute of Ecology, Techn. Univ., Rothenburgstr. 12, D 1000 Berlin (West) 41 \\ (Received: February 28, 1986. Accepted: March 19, 1986)
}

\begin{abstract}
Succession experiments were carried out in $1 \mathrm{~m}^{2}$ sized plots on three different soils ( $\mathrm{S}=$ sand, $\mathrm{SCL}=$ silty clayey loam, $\mathrm{CL}=$ clayey loam $)$. Vegetation was allowed to grow for 9 years, starting at different dates between 18.06.1969 and 1.04.1971. The greatest part of the variation of floristic composition and cover was brought about by the different soils. Direct effects of the starting season were detected only in the first two years. On sand in the first year the winter annual Conyza canadensis was well developed on the plots that had started in spring, but was poorly developed on the summer and fall plots. In the second year it decreased in the spring plots but increased in the summer and fall plots. The same was true for the winter annual Sonchus asper on CL. On SCL, however, Senecio vulgaris, belonging to the therophyta epeteia (overwintering in summer habit), was well developed in both the spring and summer plots, and showed an increase towards the second year in the fall plots only. In the later years of the experiment plots that had been started early in the year mostly were dominated by Poa pratensis ssp. angustifolia (or Quercus rubra), whereas plots that had been started late in the year mostly were dominated by Solidago canadensis together with Artemsia vulgaris. The analyses of the transition events between the (sub)dominant species showed a variety of replacement patterns, but no determinated series of species following each other. It remains, therefore, unclear in what manner the differentiation between the terminal dominants may be related to the starting season.
\end{abstract}

Key words: succession, seasonal effects, ruderal plant communities

\section{INTRODUCTION}

Communities of ruderal plants owe their existence to disturbancies of their habitat (Grime 1979). In a specific way the performance of these communities is dependent on both the physical factors and the time span of undisturbed vegetation development. Urban vegetation, therefore, has to be described in its successional state. This implies the knowledge of the ruderal succession series. In order to contribute to this knowledge a number of experiments has been carried out in the urban area of Berlin (W) 
on different soils. Preliminary results (Bornkamm and Hennig 1980) and careful evaluation of the development within the first nine years (Bornkamm and Hennig 1982, Bornkamm 1984) showed the course of floristic composition and of biomass production. They also showed a significant difference of one set of plots started in the first years's spring and another set of plots started in the summer of the subsequent years. The differences may be due to the fact that free space became available at different seasons or at different years. In order to obtain better knowledge of this problem plots were established on which the vegetation development was allowed to start at different seasons of two subsequent years. The present paper deals with changes of the floristic composition of these plots within nine years.

\section{METHODS}

In the experimental garden of the Institute of Ecology (Tech. Univ. Berlin West) in Berlin-Dahlem 4 blocks of $10 \mathrm{~m}^{2}$ size were used. Each block was subdivided into $101 \mathrm{~m}^{2}$-subplots. Two of them were filled with sand. one with silty clayey loam and one with clayey loam (for further characterization of the plots see Bornkamm and Henning (1982) and Bornkamm (1984). In every block the existing vegetation in $1 \mathrm{~m}^{2}$ was harvested in irregular intervals $(18.06 ., 28.07$. and 28.10.1969; 21.03.. 25.05. 6.07., 27.08 and $26.10 .1970 ; 1.04 .1971)$, and the plots were set free for a new succession. The seed bank in the soil was not touched. Every year in late summer phytosiological releves were made (not comprising two late blocks in the first year). The cover was estimated in steps of $1 / 10 \mathrm{~m}^{2} \quad(=10 \%)$; the figure 0 indicates a cover of less than $5 \%$ (calculated as $2.5 \%$ ).

\section{RESULTS}

The results are given in Tables 1-9. The tables show the mean cover values of the important species for years, seasons and soils. Species were regarded as important if they exhibited a cover of more than $5 \%$, in at least one of the treatments. The less important species were divided into life form groups in order to limit the number of data presented. In defining life forms we followed the ideas of Sissingh (1952), Tüxen (1958), Bakker et al. (1966) and Schmidt (1981), see also Griffioen (1980).

What concerns the relation of the species to the different soils our results in many respects confirm earlier findings and will not be discussed in detail here. 
Regarding the years it must be taken into mind that the year 1971 comprised one plot only in every block, so that the main comparison has to be carried out between 1969 and 1970. If we look at mean values which differ at least in the factor 3 at low cover $(<5 \%)$ and around the factor 2 at higher cover $(>5 \%)$ we can observe three types of reactions:

1. In the first year some species show higher values in the 1970 plots than in the 1969 plots. The contrary is true in the second year (Conyza canadensis, Sonchus asper). This is probably due to the fact,

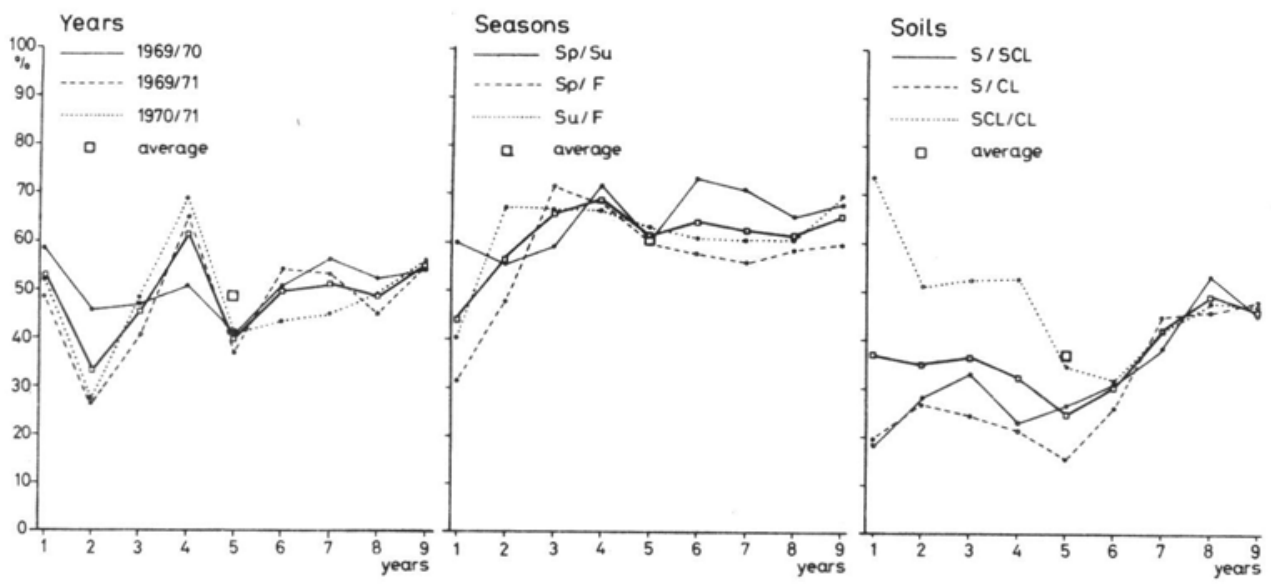

Fig. 1. Percentage similarity of the plots in relation to the starting years. seasons and the soils. For explanations see Table I

that all 1970 plots started in summer or fall, but the 1969 plots also in spring. Bromus hordeaceus (s.l., correctly: Bromus pseudothominii) and Vicia species show continuous changes but not in such a regular way.

2. In the years 3-9 a number of species preferred the 1969 plots continuously for several years: Bromus sterilis, Agrostis tenuis and Solidago canadensis. Other species were favoured by the 1970 plots: Bromus tectorum, Artemisia vulgaris, Verbascum lychnitis and Poa pratensis ssp. angustifolia. It is interesting to note that initial differences may last for a long time, and that species of the same genus (Bromus) behave differently (see also Hulbert 1955).

Concerning seasons we can make similar observations as concerning years. In the first year Senecio vulgaris, Sonchus asper and Conyza canadensis (as most other species) were best developed in the spring plots, in the second year in the summer plots. The same is true for Trifolium arvense. Apparently on the spring plots certain phases of vegetation development took place in the first year which in the fall plots were shifted into 
Table 1

Vegetation of the plots in the first year

\begin{tabular}{|c|c|c|c|c|c|c|c|c|c|c|}
\hline & & \multicolumn{3}{|c|}{ Years } & \multicolumn{3}{|c|}{ Seasons } & \multicolumn{3}{|c|}{ Soils } \\
\hline \multicolumn{2}{|l|}{ Treatment } & 1969 & 1970 & 1971 & $\mathrm{Sp}$ & $\mathrm{Su}$ & $\mathrm{F}$ & $\mathrm{S}$ & SCL & $\mathrm{CL}$ \\
\hline \multicolumn{2}{|l|}{ Number } & 8 & 16 & 4 & 12 & 8 & 8 & 14 & 7 & 7 \\
\hline \multicolumn{2}{|l|}{ Species } & 3.9 & 5.3 & 6.8 & 7.4 & 3.9 & 3.0 & 6.6 & 3.9 & 3.3 \\
\hline \multicolumn{2}{|l|}{ Cover } & 6 & 19 & 16 & 25 & 16 & 2 & 9 & 25 & 2.0 \\
\hline Name & $\begin{array}{c}\text { life } \\
\text { form }\end{array}$ & \multicolumn{9}{|c|}{ mean cover values } \\
\hline Senecio vulgaris & TE & 8.4 & 6.6 & 19.4 & 13.7 & 10.2 & 1.6 & 1.8 & 19.3 & 13.2 \\
\hline Others (4) & TE & 0.9 & 1.1 & 0.6 & 1.4 & 0.6 & 0.3 & 1.5 & 0.4 & 0.4 \\
\hline Conyza canadensis & $\mathrm{TH}$ & 1.6 & 4.2 & 1.3 & 6.0 & 0.6 & 1.6 & 5.0 & 1.1 & 1.1 \\
\hline Bromus hordeaceus & $\mathrm{TH}$ & 0.6 & 3.4 & 1.9 & 1.7 & 4.4 & 1.6 & 1.4 & 5.7 & 1.1 \\
\hline Others (8) & $\mathrm{TH}$ & 0.3 & 1.8 & 1.9 & 3.0 & 0.6 & & 3.1 & 0.4 & \\
\hline Sonchus asper & TA & 1.3 & 3.9 & 3.1 & 5.2 & 2.2 & 0.9 & 0.2 & 6.4 & 5.0 \\
\hline Others $(8)$ & TA & 0.9 & 1.5 & 1.6 & 2.6 & 1.2 & & 2.8 & 0.4 & \\
\hline (4) & $\mathrm{TB}$ & 0.9 & 1.5 & 1.3 & 0.6 & 0.9 & 0.6 & 1.3 & 0.8 & \\
\hline (1) & $\mathrm{C}$ & & & 0.6 & 0.2 & & & 0.2 & & \\
\hline (5) & $\mathrm{H}$ & 0.6 & 2.4 & 1.8 & 2.6 & 0.9 & 0.9 & 2.4 & 0.7 & 1.5 \\
\hline (2) & PJ & & 0.2 & 0.6 & 0.4 & & & 0.2 & 0.4 & 0.4 \\
\hline
\end{tabular}

Treatments: Years: plots started in $1959(18.06 . .28 .07 . .8 .10)$..1970 (21.03.. 25.05.. 6.07.. 27.08.. 26.10.) or 1971 (1.04.).

Seasons: plots started in spring $(\mathrm{Sp}=21.03-25.05$.), summer $(\mathrm{Su}=18.06-28,07$.) or fall $(\mathrm{F}=27.08,-26.10$. $)$.

Soils: plots on sand (S), silty clayey loam (SCL) or clayey loam (CL).

Number $=$ number of plots. Cover $=$ mean cover. Species $=$ mean number of species per $\mathrm{m}^{2}$. Names according to Oberdorfer 1979. Others=other species exhibiting the same life form (in brackets number of species). Life forms: C $=$ = chamaephytes, $\mathrm{H}=$ hemicryptophytes (included facultative geophytes). $\mathrm{TA}=$ summer annuals, $\mathrm{TB}=$ biennals, $\mathrm{TE}=\mathrm{ephemerals}$ overwintering in summer habit. $\mathrm{TH}=$ winter annuals. $\mathrm{PJ}=$ young phanerophytes.

the second year. Bromus hordeaceus, Bromus sterilis and the Vicia species showed rather irregular changes.

In the later succession years (3-9) the differences between the spring and the summer plots were small. In a number of cases Bromus tectorum and Agrostis tenuis were better developed on the summer plots than on the spring plots. Very rarely the spring plots were preferred (e.g. Bromus hordeaceus in the third year).

The fall plots differ stronger from the two other types of plots. Here the following species occasionally or over a longer tim span were best developed: Artemisia vulgaris, Medicago lupulina and Solidago canadensis. The contrary was true for Poa pratensis ssp. angustifolia.

In order to evaluate the influence of all species we can use measures of similarity. In Fig. 1 the values of 'percentage similarity' according to Dahl and Hadač (1941) are given. If we compare the soils in the first year we see great differences between sand (S) and loam (SCL and 
Table 2

Vegetation of the plots in the second year

\begin{tabular}{|c|c|c|c|c|c|c|c|c|c|c|}
\hline \multirow{5}{*}{$\begin{array}{l}\text { Treatment } \\
\text { Number } \\
\text { Species } \\
\text { Cover }\end{array}$} & \multirow{5}{*}{-} & \multicolumn{3}{|c|}{ Years } & \multicolumn{3}{|c|}{ Seasons } & \multicolumn{3}{|c|}{ Soils } \\
\hline & & 1969 & 1970 & 1971 & $\mathrm{Sp}$ & $\mathrm{Su}$ & $\mathrm{F}$ & $\mathrm{S}$ & SCL & $\mathrm{CL}$ \\
\hline & & 12 & 20 & 4 & 12 & 12 & 12 & 18 & 9 & 9 \\
\hline & & 12.0 & 12.8 & 7.8 & 11.4 & 13.6 & 10.9 & 13.9 & 9.9 & 10.0 \\
\hline & & 59 & 46 & 53 & 40 & 63 & 50 & 47 & 59 & 50 \\
\hline Name & $\begin{array}{c}\text { life } \\
\text { form }\end{array}$ & \multicolumn{9}{|c|}{ mean cover values } \\
\hline Senecio vulgaris & TE & 9.6 & 1.8 & & 1.3 & 5.8 & 5.4 & 1.1 & 6.9 & 7.2 \\
\hline 'Others (6) & TE & 3.1 & 1.9 & 0.6 & 0.8 & 3.3 & 2.4 & 2.7 & 0.8 & 4.5 \\
\hline Conyza canadensis & TH & 14.2 & 3.9 & 0.6 & 2.5 & 11.4 & 7.1 & 11.9 & 2.8 & 2.5 \\
\hline Bromus hordeaceus & TH & 10.5 & 5.3 & 40.6 & 18.6 & 11.3 & 2.9 & 6.3 & 16.7 & 14.4 \\
\hline Apera spica-venti & TH & 0.6 & 1.0 & 5.6 & 1.0 & 1.4 & 1.2 & 2.8 & & \\
\hline Trifolium arrense & TH & 11.8 & 6.4 & & 1.0 & 12.7 & 8.8 & 14.9 & & \\
\hline Bromus tectorum & TH & & 8.4 & & 4.0 & 6.0 & 4.0 & 1.1 & 16.1 & \\
\hline Others (12) & $\mathrm{TH}$ & 7.7 & 9.1 & 5.7 & 6.0 & 11.7 & 6.5 & 12.9 & 1.2 & 2.3 \\
\hline Sonchus asper & TA & 5.6 & 1.7 & & 0.9 & 4.4 & 3.1 & 1.1 & 3.1 & 7.2 \\
\hline Others (13) & TA & 2.0 & 0.9 & 0.6 & 1.0 & 1.6 & 1.5 & 1.7 & 1.2 & 0.9 \\
\hline Oenothera biennis & $\mathrm{TB}$ & 1.3 & 0.6 & 7.5 & 2.7 & 1.3 & 0.8 & 3.1 & 0.3 & \\
\hline Medicago lupulina & $\mathrm{TB}$ & 0.6 & 3.6 & 0.6 & 1.5 & 0.8 & 4.5 & 0.3 & 0.6 & 8.1 \\
\hline Others (3) & $\mathrm{TB}$ & 2.8 & 2.8 & 3.7 & 3.3 & 4.6 & 3.5 & 1.7 & 7.4 & 2.5 \\
\hline (2) & $\mathrm{C}$ & 0.4 & 0.1 & 0.6 & 0.4 & 0.6 & & 0.6 & 0.3 & \\
\hline Artemisia vulgaris & $\mathrm{H}$ & 0.2 & 6.3 & 1.9 & 1.9 & 1.5 & 8.2 & 1.0 & 0.6 & 13.1 \\
\hline Others (11) & $\mathrm{H}$ & 5.0 & 5.6 & 2.6 & 7.3 & 5.4 & 2.8 & 7.5 & 3.8 & 4.8 \\
\hline (4) & PJ & 0.8 & 0.8 & & 0.8 & 0.6 & 0.8 & 0.7 & 2.0 & \\
\hline
\end{tabular}

For explanations see Table 1.

CL) caused mainly by the differences in cover of Senecio vulgaris and Bromus hordeaceus on the one hand and Conyza canadensis and Trifolium arvense on the other hand (see Tables 1 and 2).

In the sixth year the difference between the loamy soils became as great as the difference between sand and loam. The most important factor was the rich development of Bromus tectorum on SCL and of Artemisia vulgaris on CL (see Tables 3-6). In the sixth year the similarity between all three sets of plots was as low as $30 \%$, but was increased during the last years. The most important feature here was the spread of dominant species like Solidago canadensis and Poa pratensis ssp. angustifolia, which show little variation between the soils.

What concerns years the differences did not exhibit any general shift but large variations. This was mainly caused by cover changes of Bromus hordeaceus. In the second half of the experiment the similarity was in the same magnitude of $50 \%$ between all three sets of plots. 
Table 3

Vegetation of the plots in the third year

\begin{tabular}{|c|c|c|c|c|c|c|c|c|c|c|}
\hline & & & Years & & 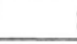 & Season & & & Soils & \\
\hline Treatment & & 1969 & 1970 & 1971 & Sp & Su & $\mathrm{F}$ & $\mathrm{S}$ & SCL & $\mathrm{CL}$ \\
\hline Number & & 12 & 20 & 4 & 12 & 12 & 12 & 18 & 9 & 9 \\
\hline Species & & 12.4 & 8.8 & 8.8 & 9.4 & 10.4 & 10.3 & 11.1 & 8.9 & 8.6 \\
\hline Cover & & 43 & 67 & 98 & 7.5 & 49 & 64 & 51 & 73 & 74 \\
\hline Name & $\begin{array}{c}\text { life } \\
\text { form }\end{array}$ & & & & mean & cover & values & & & \\
\hline (3) & TE & 2.3 & 0.3 & 0.6 & 0.6 & 1.7 & 0.8 & 0.7 & 0.6 & 2.2 \\
\hline Bromus hordeaceus & $\mathrm{TH}$ & 15.7 & 23.6 & 38.6 & 30.7 & 16.3 & 20.6 & 11.1 & 30.6 & 34.4 \\
\hline Bromus tectorum & TH & 0.4 & 14.9 & & 9.9 & 6.7 & 8.7 & 3.6 & 26.4 & \\
\hline Trifolium arvense & TH & 5.7 & 1.0 & & & 5.9 & 1.9 & 4.9 & 0.3 & \\
\hline Vicia hirsuta & TH & 0.2 & 6.1 & 12.5 & 6.5 & 1.9 & 6.2 & 9.7 & & \\
\hline Vicia tetrasperma & TH & 0.2 & 0.1 & 12.5 & 4.2 & 0.4 & & 3.1 & & \\
\hline Others (9) & TH & 8.6 & 3.9 & 3.8 & 3.9 & 6.6 & 6.6 & 9.3 & 2.6 & 2.3 \\
\hline (7) & TA & 2.2 & 0.5 & & 0.8 & 0.6 & 1.4 & 0.1 & 2.5 & 1.4 \\
\hline Oenothera biennis & TB & 4.2 & 1.6 & 11.0 & 5.9 & 2.7 & 2.9 & 6.7 & 0.6 & \\
\hline Daucus carota & TB & 0.9 & 1.9 & 6.3 & 3.6 & 0.9 & 1.9 & 1.7 & 3.6 & 1.4 \\
\hline Others (3) & TB & 5.7 & 3.5 & 3.8 & 3.9 & 4.8 & 4.0 & 0.8 & 8.3 & 6.9 \\
\hline (1) & $\mathrm{C}$ & & 0.1 & 0.6 & 0.2 & & 0.2 & 0.3 & & \\
\hline Artemisia vulgaris & $\mathrm{H}$ & 1.2 & 14.3 & 1.9 & 6.5 & 4.4 & 14.9 & 1.3 & 1.1 & 31.1 \\
\hline Rumex acetosella & $\mathrm{H}$ & 3.8 & 1.6 & 0.6 & 0.8 & 5.2 & 0.6 & 4.4 & & \\
\hline Taraxacum officinale & $\mathrm{H}$ & 2.1 & 2.4 & 3.1 & 4.2 & 1.7 & 1.3 & 0.3 & 4.7 & 6.7 \\
\hline Others (11) & $\mathrm{H}$ & 4.9 & 2.5 & 3.7 & 3.9 & 3.6 & 3.1 & 4.5 & 2.4 & 3.5 \\
\hline (7) & PJ & 1.2 & 1.0 & 1.3 & 1.2 & 0.8 & 1.4 & 1.3 & 2.3 & \\
\hline
\end{tabular}

For explanations see Table I.

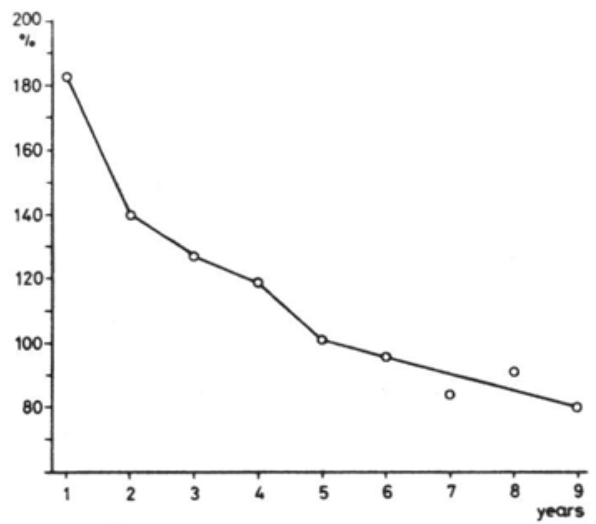

Fig. 2. Species number on sand as a percentage of the species number on loam 
Table 4

Vegetation of the plots in the fourth year

\begin{tabular}{|c|c|c|c|c|c|c|c|c|c|c|}
\hline \multirow{2}{*}{ Treatment } & & \multicolumn{3}{|c|}{ Years } & \multicolumn{3}{|c|}{ Seasons } & \multicolumn{3}{|c|}{ Soils } \\
\hline & & 1969 & 1970 & 1971 & $\mathrm{Sp}$ & $\mathrm{Su}$ & $\mathrm{F}$ & $\mathrm{S}$ & SCL & $\mathrm{CL}$ \\
\hline \multirow{3}{*}{\multicolumn{2}{|c|}{$\begin{array}{l}\text { Númber } \\
\text { Species } \\
\text { Cover }\end{array}$}} & 12 & 20 & 4 & 12 & 12 & 12 & 18 & 9 & 9 \\
\hline & & 8.4 & 7.3 & 9.8 & 8.3 & 7.9 & 7.7 & 8.6 & 8.1 & 6.3 \\
\hline & & 64 & 76 & 70 & 69 & 68 & 77 & 53 & 88 & 90 \\
\hline Name & $\begin{array}{c}\text { life } \\
\text { form }\end{array}$ & \multicolumn{9}{|c|}{ mean cover values } \\
\hline (2) & TE & & 0.2 & & & & 0.2 & & 1.4 & \\
\hline Bromus hordeaceus & TH & 40.3 & 22.0 & 28.0 & 23.5 & 32.3 & 25.3 & 6.9 & 26.3 & 41.1 \\
\hline Bromus tectorum & TH & 0.2 & 5.5 & 0.6 & 0.4 & 6.7 & 2.3 & 0.4 & 5.8 & \\
\hline Vicia hirsuta & TH & 2.5 & 5.7 & 2.5 & 2.7 & 3.3 & 6.9 & 8.5 & 0.1 & \\
\hline Vicia tetrasperma & TH & & 5.6 & 2.5 & 2.7 & 2.5 & 6.7 & 6.8 & & \\
\hline Others $(8)$ & $\mathrm{TH}$ & 3.6 & 0.6 & & 6.0 & 3.4 & 1.0 & 3.8 & 0.6 & 2.3 \\
\hline (2) & TA & 0.2 & 0.1 & 0.6 & 0.2 & 0.2 & & 0.1 & 0.1 & \\
\hline Oenothera biennis & $\mathrm{TB}$ & 2.1 & 8.7 & 2.5 & 6.9 & 3.6 & 10.4 & 13.6 & 0.3 & \\
\hline Others (4) & $\mathrm{TB}$ & 3.2 & 5.7 & 3.1 & 7.0 & 3.8 & 4.2 & 2.3 & 6.0 & 3.9 \\
\hline (1) & $\mathrm{C}$ & & 0.1 & & 0.2 & & 0.2 & 0.3 & & \\
\hline Artemisia vulgaris & $\mathrm{H}$ & 4.6 & 18.2 & 15.0 & 10.9 & 7.7 & 17.5 & 2.5 & 0.8 & 20.7 \\
\hline Rumex acetosella & $\mathrm{H}$ & 4.6 & 2.2 & 2.5 & 2.0 & 6.0 & 2.1 & 5.7 & & \\
\hline Others (11) & $\mathrm{H}$ & 7.0 & 10.3 & 12.5 & 11.2 & 7.3 & 9.8 & 9.7 & 5.3 & 4.9 \\
\hline (7) & PI & 2.2 & 1.6 & 2.5 & 1.2 & 1.8 & 2.4 & 2.3 & 2.5 & \\
\hline
\end{tabular}

For explanations see Table 1 .
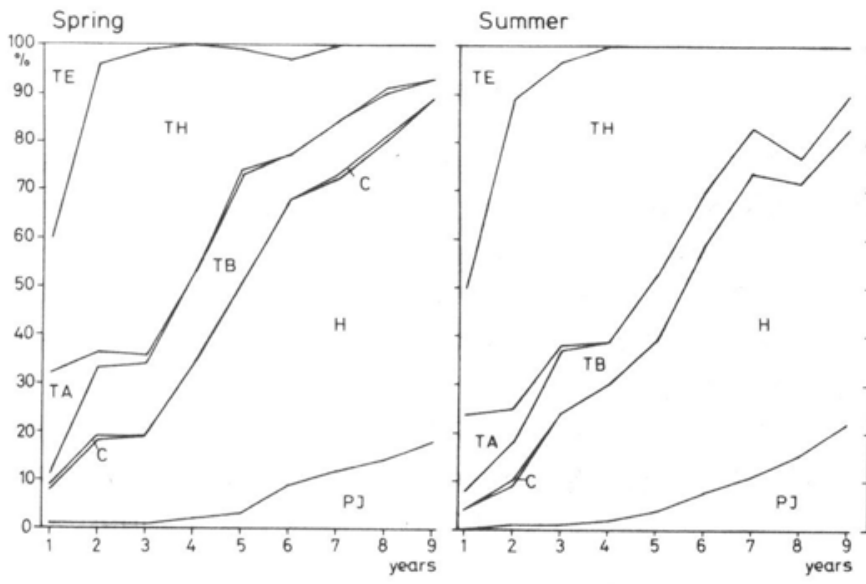

fall

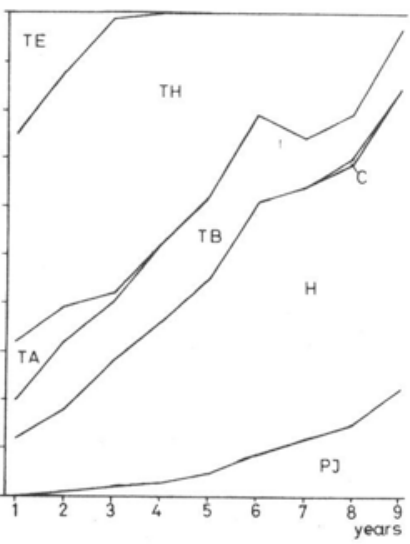

Fig. 3. Mean cover of life form groups on plots started in spring summer or fall (in \% of total cover). For explanations see Table I 
Table 5

Vegetation of the plots in the fifth year

\begin{tabular}{|c|c|c|c|c|c|c|c|c|c|c|}
\hline \multirow{2}{*}{\multicolumn{2}{|c|}{$\begin{array}{l}\text { Treatment } \\
\text { Number } \\
\text { Species } \\
\text { Cover }\end{array}$}} & \multicolumn{3}{|c|}{ Years } & \multicolumn{3}{|c|}{ Seasons } & \multicolumn{3}{|c|}{ Soils } \\
\hline & & $\begin{array}{c}1969 \\
12 \\
8.5 \\
78\end{array}$ & $\begin{array}{c}1970 \\
20 \\
8.3 \\
76\end{array}$ & $\begin{array}{c}1971 \\
4 \\
9.3 \\
80\end{array}$ & $\begin{array}{c}\text { Sp } \\
12 \\
9.2 \\
73\end{array}$ & $\begin{array}{c}\mathrm{Su} \\
12 \\
8.2 \\
78\end{array}$ & $\begin{array}{c}\mathrm{F} \\
12 \\
8.0 \\
80\end{array}$ & $\begin{array}{c}\mathrm{S} \\
18 \\
8.4 \\
61\end{array}$ & $\begin{array}{c}\text { SCL } \\
9 \\
8.9 \\
92\end{array}$ & $\begin{array}{c}\mathrm{CL} \\
9 \\
7.8 \\
94\end{array}$ \\
\hline Name & \begin{tabular}{|c|} 
life \\
form
\end{tabular} & \multicolumn{9}{|c|}{ mean cover values } \\
\hline (2) & TE & & 0.2 & & 0.4 & & & 0.1 & 0.3 & \\
\hline Bromus hordeaceus & TH & 36.0 & 4.2 & 3.8 & 6.5 & 25.4 & 12.4 & 0.7 & 39.2 & 22.5 \\
\hline Bromus tectorum & TH & & 9.0 & & 1.3 & 6.0 & 7.7 & 3.2 & 13.6 & \\
\hline Bromus sterilis & TH & 0.2 & 0.2 & 22.5 & 7.7 & 0.2 & 0.2 & 0.1 & & 10.6 \\
\hline Vicia hirsuta & $\mathrm{TH}$ & 5.5 & 1.1 & 0.6 & 1.0 & 4.4 & 2.5 & 5.3 & & \\
\hline Vicia tetrasperma & TH & 5.5 & 0.7 & & 0.8 & 4.4 & 1.9 & 4.7 & & \\
\hline Vicia sativa ssp. ang. & TH & 0.2 & 5.7 & 1.3 & 1.9 & 1.2 & 7.0 & 6.7 & & \\
\hline Others (1) & TH & & & 0.6 & 0.2 & & & 0.1 & & \\
\hline (2) & TA & 0.2 & 0.1 & 0.6 & 0.4 & 0.2 & & & 0.6 & 0.3 \\
\hline Oenothera biennis & TB & 5.1 & 7.7 & 8.8 & 7.3 & 5.7 & 7.9 & 13.6 & 0.6 & 0.3 \\
\hline Daucus carota & $\mathrm{TB}$ & 1.1 & 3.5 & 6.9 & 5.2 & 1.3 & 2.7 & 4.0 & 2.5 & 1.7 \\
\hline Verbascum lychnitis & TB & 0.4 & 4.6 & & 2.9 & 2.9 & 2.3 & 0.1 & 6.7 & 3.9 \\
\hline Others (2) & TB & 2.5 & 1.4 & 0.6 & 1.3 & 2.1 & 1.6 & 0.5 & 2.8 & 2.7 \\
\hline (1) & $\mathrm{C}$ & & 0.1 & 0.6 & 0.2 & & 0.2 & 0.3 & 0.6 & 0.6 \\
\hline Artemisia vulgaris & $\mathrm{H}$ & 5.8 & 18.8 & 1.9 & 12.1 & 7.1 & 18.6 & 1.7 & 1.1 & 45.8 \\
\hline Taraxacum officinale & $\mathrm{H}$ & 1.9 & 2.5 & 3.1 & 3.7 & 1.9 & 1.5 & 0.4 & 6.9 & 5.0 \\
\hline Solidago canadensis & $\mathrm{H}$ & 11.7 & 4.2 & 11.0 & 5.4 & 7.4 & 9.7 & 11.0 & 4.2 & 3.6 \\
\hline Poa pratensis ssp. ang. & $\mathrm{H}$ & 3.5 & 5.7 & 16.0 & 8.8 & 9.1 & 0.2 & 6.7 & 9.3 & 1.9 \\
\hline Others (12) & $\mathrm{H}$ & 5.4 & 4.3 & 9.3 & 7.1 & 5.0 & 3.7 & 4.7 & 5.4 & 5.1 \\
\hline (9) & PJ & 4.9 & 2.7 & 1.3 & 2.3 & 3.7 & 4.1 & 3.9 & 5.6 & 0.3 \\
\hline
\end{tabular}

For explanations see Table 1.

Looking at seasons we can observe a great difference between the fall plots and the other plots in the first year. In the second year these differences diminish, but still in the second half of the experiment the similarity between the spring and summer plots was greater than the similarity to the fall plots. This was mainly due to the fact that the ratio Poa pratensis ssp. angustifolia: Solidago canadensis was $>1$ in the spring and summer plots but $<1$ in the fall plots (see Tables 5-9). On the average the similarity between the plots started at different seasons was greater $(61 \%)$ than the similarity of the plots started in different years $(49 \%)$ or on different soils $(37 \%)$.

The species number was lower in the first years in the fall plots and the 1969 plots than in the other ones, but later on no distinct differences occurred between the years and the seasons. In the first half 
Table 6

Vegetation of the plots in the sixth year

\begin{tabular}{|c|c|c|c|c|c|c|c|c|c|c|}
\hline \multirow{2}{*}{\multicolumn{2}{|c|}{ Treatment }} & \multicolumn{3}{|c|}{ Years } & \multicolumn{3}{|c|}{ Seasons } & \multicolumn{3}{|c|}{ Soils } \\
\hline & & 1969 & 1970 & 1971 & $\mathrm{Sp}$ & $\mathrm{Su}$ & $\mathrm{F}$ & S & $\mathrm{SCL}$ & $\mathrm{CL}$ \\
\hline \multirow{3}{*}{\multicolumn{2}{|c|}{$\begin{array}{l}\text { Number } \\
\text { Species } \\
\text { Cover }\end{array}$}} & 12 & 20 & 4 & 12 & 12 & 12 & 18 & 9 & 9 \\
\hline & & 9.4 & 7.5 & 11.0 & 8.8 & 8.5 & 8.1 & 8.3 & 9.4 & 7.9 \\
\hline & & 80 & 74 & 80 & 74 & 73 & 83 & 64 & 83 & 94 \\
\hline Name & $\begin{array}{c}\text { life } \\
\text { form }\end{array}$ & \multicolumn{9}{|c|}{ mean cover values } \\
\hline (2) & $\mathrm{TE}$ & 0.2 & 2.5 & & 2.5 & 0.2 & & 0.1 & 3.3 & \\
\hline Bromus hordeaceus & $\mathrm{TH}$ & 9.1 & 7.4 & 3.1 & 5.2 & 7.4 & 9.8 & 0.3 & 28.3 & 0.8 \\
\hline Bromus sterilis & $\mathrm{TH}$ & 6.0 & 2.8 & 23.0 & 7.7 & 6.0 & 4.6 & 2.9 & & 18.3 \\
\hline Vicia hirsuta & $\mathrm{TH}$ & 0.6 & & 3.1 & 1.0 & 0.6 & & 1.1 & & \\
\hline Vicia tetrasperma & $\mathrm{TH}$ & 10.0 & & 8.1 & 2.7 & 7.5 & 2.5 & 8.5 & & \\
\hline Others (5) & $\mathrm{TH}$ & 1.7 & 2.1 & 2.5 & 1.2 & 3.9 & 0.8 & 2.0 & 3.9 & \\
\hline (2) & $\mathrm{TA}$ & 0.2 & 0.2 & & 0.2 & 0.2 & 0.2 & & 0.9 & 0.3 \\
\hline Oenothera biennis & TB & 2.7 & 3.0 & 4.4 & 2.9 & 2.7 & 3.6 & 5.7 & 1.1 & 0.3 \\
\hline Verbascum lychnitis & TB & 1.2 & .4 .1 & & 2.1 & 2.7 & 3.3 & 0.1 & 6.4 & 4.2 \\
\hline Medicago lupulina & $\mathrm{TB}$ & 6.2 & 0.4 & & 0.2 & 1.2 & 5.4 & 0.1 & 1.9 & 6.9 \\
\hline Others (2) & $\mathrm{TB}$ & 2.7 & 2.3 & 2.5 & 2.3 & 2.5 & 2.7 & 2.8 & 2.3 & 2.2 \\
\hline (1) & $\mathrm{H}$ & & 0.2 & 0.6 & 0.4 & & 0.2 & 0.4 & & \\
\hline Artemisia vulgaris & $\mathrm{H}$ & 8.0 & 19.3 & 1.3 & 11.9 & 9.0 & 19.7 & 1.5 & 3.9 & 46.9 \\
\hline Taraxacum officinale & $\mathrm{H}$ & 1.3 & 3.9 & 3.1 & 5.4 & 1.9 & 1.5 & 0.3 & 4.2 & 7.2 \\
\hline Solidago canadensis & $\mathrm{H}$ & 19.3 & 7.9 & 20.0 & 10.0 & 11.0 & 17.2 & 19.0 & 7.2 & 6.7 \\
\hline Poa pratensis ssp. ang. & $\mathrm{H}$ & 3.1 & 13.4 & 12.5 & 16.2 & 12.5 & 1.0 & 12.1 & 8.3 & 6.7 \\
\hline Others (14) & $\mathrm{H}$ & 7.9 & 3.6 & 15.7 & 8.2 & 7.1 & 4.3 & 6.0 & 8.5 & 6.5 \\
\hline Sarothamnus scoparius & PJ & 5.8 & 0.2 & 0.6 & 0.4 & & & 4.3 & & \\
\hline Quercus rubra & & 2.7 & 4.2 & & 6.7 & 2.7 & 0.4 & 2.1 & 10.0 & \\
\hline Others (6) & PJ & 1.8 & 2.6 & 1.3 & 0.8 & 4.1 & 1.6 & 1.8 & 5.0 & 0.3 \\
\hline
\end{tabular}

For explanations see Table 1.

of the experiment the species number on the sandy soil was higher than on the loamy soils, whereas it was lower in the second half (Fig. 2).

Likewise the mean cover was lower in the fall plots and the 1969 plots in the first year only. No distinct differences appeared between the years and the seasons later on. What concerns soil the mean cover on sand was continuously lower than on sand.

From the Tables 1-9 it becomes clear that the greatest floristic variation is caused by the different soils. But in the view of our problem the differences caused by seasons (and years) are more interesting. In order to have a closer look at these the cover of the different life form groups expressed as percentage of the total of the cover values of all species is given in Fig. 3. At the first impression the three graphs in Fig. 3 look very similar, and the change from dominating therophytes 
Table 7

Vegetation of the plots in the seventh year

\begin{tabular}{|c|c|c|c|c|c|c|c|c|c|c|}
\hline & & & Years & & & eason & & & Soils & \\
\hline Treatment & & 1969 & 1970 & 1971 & $\mathrm{Sp}$ & $\mathrm{Su}$ & $\mathrm{F}$ & S & SCL & $\mathrm{CL}$ \\
\hline Number & & 12 & 20 & 4 & 12 & 12 & 12 & 18 & 9 & 9 \\
\hline Species & & 7.0 & 9.6 & 9.8 & 9.5 & 7.4 & 9.3 & 7.8 & 10.3 & 8.3 \\
\hline Cover & & 84 & 70 & 75 & 68 & 83 & 75 & 66 & 84 & 83 \\
\hline Name & $\begin{array}{c}\text { life } \\
\text { form }\end{array}$ & & & & mean & cover & values & & & \\
\hline Bromus hordeaceus & $\mathrm{TH}$ & 11.9 & 5.8 & & 0.6 & 8.7 & 8.9 & 0.1 & 27.2 & 1.4 \\
\hline Bromus sterilis & TH & 6.9 & 2.5 & 10.0 & 3.3 & 6.7 & 4.4 & 1.8 & & 15.6 \\
\hline Vicia hirsuta & TH & & 3.2 & 23.0 & 9.5 & & 3.5 & 8.5 & 0.3 & \\
\hline Vicia tetrasperma & TH & & 1.9 & & & 0.4 & 2.7 & 2.1 & & \\
\hline Others (5) & TH & 0.4 & 4.8 & 1.3 & 1.3 & 1.0 & 4.1 & 3.9 & 3.9 & 0.3 \\
\hline (1) & TA & 0.2 & & & & 0.2 & & & 0.3 & \\
\hline Oenothera biennis & TB & 1.7 & 3.0 & 8.1 & 3.3 & 2.5 & 3.6 & 5.7 & 1.1 & \\
\hline Verbascum lychnitis & TB & 0.2 & 5.1 & & 2.9 & 3.3 & 2.5 & 0.1 & 5.3 & 6.1 \\
\hline Others (3) & TB & 3.1 & 2.7 & 6.3 & 3.7 & 2.9 & 3.1 & 2.4 & 3.9 & 4.2 \\
\hline (2) & $\mathrm{C}$ & & 0.3 & 0.6 & 0.6 & & 0.2 & 0.5 & & \\
\hline Artemisia vulgaris & $\mathrm{H}$ & 9.1 & 9.1 & 2.5 & 4.4 & 7.4 & 13.4 & 2.5 & 2.2 & 27.8 \\
\hline Taraxacum officinale & $\mathrm{H}$ & 3.4 & 3.0 & 8.1 & 5.0 & 2.5 & 3.6 & 0.7 & 6.1 & 8.3 \\
\hline Solidago canadensis & $\mathrm{H}$ & 24.7 & 9.5 & 17.5 & 13.1 & 14.9 & 18.3 & 20.0 & 8.9 & 13.1 \\
\hline Poa pratensis ssp. ang. & $\mathrm{H}$ & 7.6 & 25.8 & 15.0 & 22.7 & 28.2 & 4.8 & 20.3 & 11.7 & 20.3 \\
\hline Convolvulus arvensis & $\mathrm{H}$ & 0.6 & 0.6 & 8.8 & 3.3 & 0.8 & 0.4 & 0.8 & 0.3 & 4.2 \\
\hline Agrostis tenuis & $\mathrm{H}$ & 8.1 & 2.3 & 0.6 & 3.1 & 7.9 & 1.1 & 5.0 & 4.7 & 1.4 \\
\hline Hypochoeris radicata & $\mathrm{H}$ & 1.5 & 2.6 & 1.9 & 2.1 & 1.9 & 2.5 & 0.6 & 6.1 & 1.7 \\
\hline Others $(10)$ & $\mathrm{H}$ & 1.0 & 1.0 & 6.8 & 3.3 & 0.8 & 1.0 & 0.5 & 4.0 & 1.7 \\
\hline Sarothamus scoparius & PJ & 6.0 & 0.4 & 5.0 & 2.3 & 0.2 & 6.2 & 5.7 & & 0.3 \\
\hline Quercus rubra & PJ & 6.8 & 5.7 & & 7.7 & 7.0 & 1.7 & 4.2 & 13.3 & \\
\hline Corylus avellana & PJ & & 2.5 & & & 3.2 & & & 5.6 & \\
\hline Others (9) • & PJ & 1.6 & 1.9 & 1.3 & 1.2 & 1.0 & 3.1 & 2.8 & 3.1 & 0.8 \\
\hline
\end{tabular}

For explanations see Table 1.

to dominating hemicryptophytes needs no interpretation. Nevertheless differences occur in the first, and partly in the second year. In the first year the percentage of the therophyta epeteia (TE) was much higher on the spring plots $(40 \%)$ and the summer plots $(50 \%)$ than on the fall plots $(25 \%)$. On the other hand the percentage of the winter annuals (TH) and hemicryptophytes (H) was higher in the falt plots $(\mathrm{TH} 43 \%$; $\mathrm{H} 12 \%$ ) than in the spring plots (TH $28 \%$; $7 \%$ ) or the summer plots (TH $26 \%$; $4 \%$ ). This was mainly due to the high cover values of Senecio vulgaris in the spring and summer plots and the (relatively) good performance of Conyza canadensis and Bromus hordeaceus on the fall plots. 
Table 8

Vegetation of the plots in the eighth year

\begin{tabular}{|c|c|c|c|c|c|c|c|c|c|c|}
\hline & & & Years & & & eason: & & & Soils & \\
\hline Treatment & & 1969 & 1970 & 1971 & $\mathrm{Sp}$ & $\mathrm{Su}$ & $\mathrm{F}$ & S & SCL & CL \\
\hline Number & & 12 & 20 & 4 & 12 & 12 & 12 & 18 & 9 & 9 \\
\hline Species & & 9.5 & 11.1 & 9.5 & 10.4 & 9.3 & 11.5 & 9.9 & 11.9 & 9.8 \\
\hline Cover & & 86 & 75 & 63 & 75 & 87 & 70 & 73 & 83 & 79 \\
\hline Name & $\begin{array}{c}\text { life } \\
\text { form }\end{array}$ & & & & mean & cover & values & & & \\
\hline (1) & TE & 0.2 & & & & 0.2 & & 0.1 & & \\
\hline Bromus hordeaceus & TH & 5.2 & 0.5 & 0.6 & 0.4 & 1.1 & 4.8 & 0.6 & 6.9 & 0.6 \\
\hline Bromus sterilis & $\mathrm{TH}$ & 6.2 & 0.5 & 5.0 & 1.9 & 6.0 & .0 .8 & 0.4 & & 10.8 \\
\hline Vicia hirsuta & $\mathrm{TH}$ & 10.2 & 4.0 & 2.5 & 2.1 & 8.3 & 7.2 & 12.9 & & \\
\hline Vicia sativa ssp. ang. & $\mathrm{TH}$ & 1.5 & 7.7 & 0.6 & 3.3 & 5.6 & 5.5 & 9.4 & 0.3 & \\
\hline Others $(7)$ & TA & 4.1 & 2.8 & 0.6 & 2.1 & 3.7 & 3.2 & 4.3 & 3.7 & \\
\hline (3) & $\mathrm{TB}$ & & 0.3 & 0.6 & 0.6 & & 0.2 & 0.1 & 0.6 & 0.3 \\
\hline (5) & $\mathrm{C}$ & 5.0 & 10.3 & 5.7 & 9.0 & 5.2 & 9.0 & 5.1 & 8.3 & 13.1 \\
\hline (3) & $\mathrm{H}$ & & 0.5 & 0.6 & 0.6 & & 0.6 & 0.8 & & \\
\hline Artemisia vulgaris & $\mathrm{H}$ & 6.8 & 7.3 & 1.9 & 4.6 & 6.0 & 9.0 & 2.8 & 3.6 & 19.4 \\
\hline Taraxacum officinale & $\mathrm{H}$ & 1.9 & 5.7 & 1.3 & 5.2 & 2.1 & 4.6 & 1.0 & 3.9 & 9.7 \\
\hline Solidago canadensis & $\mathrm{H}$ & 23.7 & 11.9 & 6.3 & 9.8 & 13.8 & 22.0 & 18.9 & 20.6 & 14.4 \\
\hline Poa pratensis ssp. ang. & $\mathrm{H}$ & 9.7 & 34.4 & 20.0 & 37.0 & 25.4 & 11.4 & 24.2 & 17.2 & 32.2 \\
\hline Agrostis tenuis & $\mathrm{H}$ & 14.1 & 3.5 & & 4.4 & 12.2 & 3.3 & 6.0 & 13.3 & 1.7 \\
\hline Hypochoeris radicata & $\mathrm{H}$ & 4.5 & 2.4 & 1.3 & 2.5 & 1.3 & 5.1 & 0.1 & 9.2 & 2.5 \\
\hline Others (10) & $\mathrm{H}$ & 1.2 & 2.0 & 10.6 & 5.4 & 1.2 & 1.8 & 1.0 & 5.1 & 3.9 \\
\hline Sarothamnus scoparius & PJ & 5.4 & 3.2 & 5.0 & 5.2 & 1.2 & 6.0 & 8.3 & & 0.3 \\
\hline Quercus rubra & PJ & 9.2 & 7.0 & & 8.3 & 9.2 & 3.3 & 5.6 & 1.7 & \\
\hline Corylus avellana & PJ & & 0.1 & & & 5.0 & & 6.7 & & \\
\hline Others (10) & PJ & 4.1 & 5.9 & 1.8 & 1.4 & 1.4 & 6.7 & 3.9 & 4.0 & 0.8 \\
\hline
\end{tabular}

For explanations see Table I.

\section{DISCUSSION}

The results revel differences of floristic composition and structure of the vegetation concerning all three variables: soils, years and seasons. The differences caused by the soils in most respects are in accordance with earlier findings (Bornkamm and Hennig 1982, Bornkamm 1984). Thus, they will not be discussed here. The differences between the plots started in 1969 and 1970, occurring in the first and second year, can be explained by the fact that the 1969 plots comprised only summer and fall plots, whereas the 1970 plots comprised all seasons, and the 1971 plots are spring plots. There is no evidence that the import of diaspores was different within this span of two years, or this possible difference 
Table 9

Vegetation of the plots in the ninth year

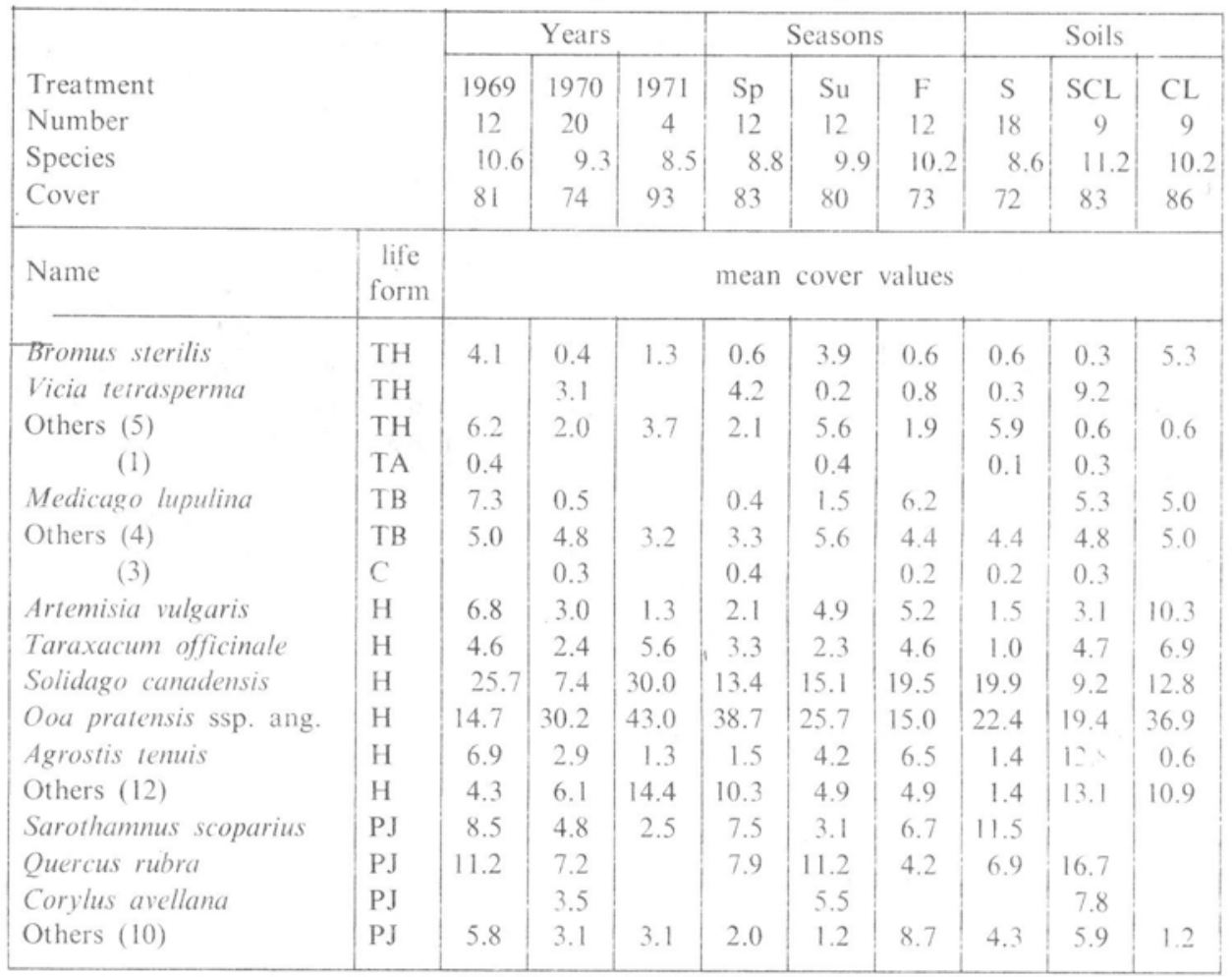

For explanations see Table 1.

was hidden behind the fact that all plots more or less provided the same seed bank. This is in contrast to experiments with longer duration. where the immigration of seeds and fruits varied with the years and therefore. invasions occurred (Bornkamm 1985a, b).

Since the effects of years and seasons are interrelated by the design of our experiment, we may lay special attention upon the differences caused by the starting season. Here three groups of results were visible: a) distinct changes of the vegetation's floristic composition and structure in the first two years, b) irregular changes of a number of species in the following years, c) differences in the species finally becoming dominant.

a. The differences in the first and second year are made up by a small number of species (see Tables 1, 2, Figs. 1, 3). The successional processes going on differ with the soils. On sand in the first year Conyza canadensis is the most frequent plant, but is, as all other species too, poorly developed in the summer and fall plots. In the second year it decreases 
in the spring plots but reaches maximum values in the summer $(18.8 \%)$ and the fall plots $(14.2 \%)$. Trifolium arvense in the first year rarely occurs in the spring plots, but not in the other ones. In the second year it still decreases in the spring plots but reaches maximum values in the summer $(25 \%)$ and the fall plots $(17.5 \%)$. Especially Trifolium arvense behaved as a true winter annual (Griffioen 1980), whereas Conyza canadensis is able to perform different types of life cycles (see the discussion with Bornkamm 1984). The differing values of the two species on the spring plots in the first year may be due to the fact, that Trifolium has the higher temperature requirement for germination than Conlza has (Grime et al. 1981).

On silty clayey loam in the spring and summer plots Senecio vulgaris is the most frequent species in the first year, but decreases in the second year. This species, that endures the winter in summer habit (TE, see Fig. 3) and shows a wide range of germination temperatures with high optimum (Lauer 1953, Grime et al. 1981), apparently able to start successful growth still in the summer. The increase from the first to the second year can be observed in the fall plots only. Several other species show a great increase from the first to the second year, namely Bromus hordeaceus in the spring and summer plots and Bromus tectorum in the summer and fall plots.

On clayey loam Senecio vulgaris again is frequent in the spring and summer plots. In plots it decreased towards the second year, while it increased in the fall plots. Species poorly developing in the first year but exhibiting a great increase from the first to the second year are Bromus hordeaceus (spring and summer plots) and Artemisia vulgaris and Medicago lupulina (fall plots).

Thus we can state on all soils a change of dominance according to the life cycles of the species. In the first year only one species can establish fully in the summer plots, namely Senecio vulgaris belonging to the therophyta epeteia, whereas this is true for the winter annuals Conyza canadensis and Sonchus asper only in the spring plots. Since the differences in the first two years are based mainly on the behaviour of the short living plants it is not surprising that differences become smaller in the third year.

b. In the following year a number of species show irregular changes, especially the Bromus and Vicia species. From these Bromus hordeaceus is well developed on all soils whereas Bromus tectorum prefers the silty clayey loam. Bromus sterilis the clayey loam, and the Vicia species sand. All of them are annuals with large seeds, which is a sign of competitive rather than ruderal strategy (Grime 1979). They can compete with perennial vegetation and may occur rather a long time in the course of succession 
Table 10

Significance of the correlation between the cover of dominant plants and the strating date of the plot $(21.03 .=$ day 80 until $26.10 .=$ day 299)

\begin{tabular}{|l|c|c|c|c|c|c|c|c|}
\hline \multirow{2}{*}{ Species } & \multicolumn{7}{|c|}{ Years } & Mean \\
\cline { 2 - 9 } & 3 & 4 & 5 & 6 & 7 & 8 & 9 & $4-8$ \\
\hline Poa pratensis ssp. angustifolia & - & - & 0 & - & 0 & - & - & - \\
Poa pratensis ssp. ang. +Quercus rubra & $(-)$ & - & $(-)$ & - & $(-)$ & - & - & - \\
Solidago canadensis + Artemisia vulgaris & 0 & 0 & + & 0 & 0 & 0 & + & + \\
\hline
\end{tabular}

,-+- Significant at the $5 \%$ level, $(-)-$ tendency at the $10 \%$ level, $0-$ not significant.

(as discussed already with Bornkamm and Henning 1982). In old meadows Bromus hordeaceus is favoured by open spots and late mowing (Klapp 1954 , p. 324). There is no evidence that these irregular changes are caused by the season of the beginning of the experiment.

c. A small number of effects is not restricted to the first years but stays throughout the experiment ending up in the dominance of different species. This is especially true for Poa pratensis ssp. angustifolia (often associated with Quercus rubra) and Solidago canadensis, often associated with Artemisia vulgaris. In some years there is a negative correlation (or at least such a tendency) between the cover value of the first two species with the starting point of the experiment, whereas the two latter species sometimes show a positive correlation (Table 10).

One possible explanation for this distribution of plants is the hypothesis that the first year acts as a switch consequently leading to a continuous difference between the fall and the other plots. This would imply the idea of a distinct series of species following each other. In order to prove this hypothesis gains or loss of dominance (cover $>15 \%$ ) are put together in Table 11. Here was separated between 'direct change', i.e. a change where one species looses but the other gains dominance, and indirect change', where the subsequent species gains dominance, but the preceding one keeps it. By this means overlapping changes were detected. From Table 11 it becomes clear that the a change from a situation without dominant species to one with dominant species is carried out most frequently by Bromus hordeaceus. This may occur in the first year, but also later on (see average year $2.9 \pm 0.9$ ). The same role is played by Senecio vulgaris and Conyza canadensis mostly in the first years, and less frequently by Artemisia vulgaris and Trifolium arvense, often in later years. All these changes, of course, are direct.

Bromus hordeaceus is replaced most frequently by Artemisia vulgaris (in the sixth year in the average), but furthermore by a variety of not less than 16 species! If this change is carried out by Oenothera biennis, 
Table 11

Changes of (sub)dominant species (cover $>15 \%$ )

\begin{tabular}{|c|c|c|c|c|c|}
\hline \multirow{2}{*}{ Preceding species } & \multirow{2}{*}{ Subsequent species } & \multicolumn{3}{|c|}{ Changes } & \multirow{2}{*}{$\begin{array}{c}\text { Average } \\
\text { year }\end{array}$} \\
\hline & & total & direct & indirect & \\
\hline none & Bromus hordeaceus & 17 & 17 & - & $2.9 \pm 0.9$ \\
\hline none & Senecio vulgaris & 12 & 12 & - & $1.6 \pm 0.8$ \\
\hline none & Conyza canadensis , & 10 & 10 & - & $2.1 \pm 1.1$ \\
\hline Bromus hordeaceus & Artemisia vulgaris & 8 & 2 & 6 & $5.8 \pm 1.0$ \\
\hline none & Artemisia vulgaris & 7 & 7 & - & $4.0 \pm 2.0$ \\
\hline none & Trifolium arvense & 6 & 6 & - & $2.7 \pm 0.8$ \\
\hline Vicia hirsuta & Oenothera biennis & 6 & 3 & 3 & $5.2 \pm 0.4$ \\
\hline Vicia tetrasperma & Solidago canadensis & 6 & 1 & 5 & $6.0 \pm 1.8$ \\
\hline Artemisia vulgaris & Poa pratensis ssp. ang. & 6 & 2 & 4 & $7.8 \pm 2.0$ \\
\hline Oenothera biennis & Poa pratensis ssp. ang. & 6 & 5 & 1 & $3.5 \pm 1.9$ \\
\hline none & Poa pratensis ssp. ang. & 5 & 5 & - & $5.6 \pm 2.1$ \\
\hline Vicia hirsuta & Poa pratensis ssp. ang. & 5 & 2 & 3 & $7.6 \pm 1.5$ \\
\hline Bromus hordeaceus & Vicia hirsuta & 5 & 5 & - & $4.0 \pm 1.0$ \\
\hline Bromus hordeaceus & Vicia tetrasperma & 5 & 5 & - & $4.0 \pm 1.0$ \\
\hline none & Sonchus asper & 5 & 5 & - & $1.4 \pm 0.9$ \\
\hline Senecio vulgaris & Bromus hordeaceus & 5 & 5 & - & $2.4 \pm 1.1$ \\
\hline Bromus hordeaceus & Oenothera biennis & 4 & 3 & 1 & $3.3 \pm 1.0$ \\
\hline Bromus hordeaceus & Verbascum lychnitis & 4 & 3 & 1 & $4.3 \pm 2.2$ \\
\hline Taraxacum officinale & Artemisia vulgaris & 4 & 2 & 2 & $2.5 \pm 1.3$ \\
\hline Solidago canadensis & Sarothamnus scoparius & 3 & 3 & - & $8.3 \pm 0.6$ \\
\hline Bromus hordeaceus & Poa pratensis ssp. ang. & 3 & 1 & 2 & $4.7 \pm 2.5$ \\
\hline none & Oenothera biennis & 3 & 3 & - & $3.0 \pm 1.0$ \\
\hline Vicia hirsuta & Solidago canadensis & 3 & 1 & 2 & $7.7 \pm 1.5$ \\
\hline Vicia hirsuta & Quercus rubra & 3 & 2 & 1 & $7.7 \pm 1.5$ \\
\hline Bromus sterilis & Poa pratensis ssp. ang. & 3 & 3 & - & $8.3 \pm 0.6$ \\
\hline Bromus hordeaceus & Solidago canadensis & 3 & 1 & 2 & $5.3 \pm 1.2$ \\
\hline none & Taraxacum officinale & 3 & 3 & - & $4.7 \pm 2.9$ \\
\hline Artemisia vulgaris & Solidago canadensis & 3 & 2 & 1 & $7.0 \pm 2.0$ \\
\hline Oenothera biennis & Solidago canadensis & 3 & 2 & 1 & $5.7 \pm 0.6$ \\
\hline none & 13 different & 13 & 13 & - & $3.9 \pm 2.4$ \\
\hline 13 different & Poa pratensis ssp. ang. & 17 & 7 & 10 & $8.1 \pm 1.5$ \\
\hline 10 different & Bromus hordeaceus & 14 & 8 & 6 & $4.3 \pm 1.7$ \\
\hline 8 different & Oenothera biennis & 9 & 3 & 6 & $4.8 \pm 1.3$ \\
\hline 7 different & Agrostis tenuis & 7 & 5 & 2 & $8.1 \pm 9.0$ \\
\hline 6 different & Artemisia vulgaris & 8 & 4 & 4 & $7.1 \pm 1.7$ \\
\hline 6 different & Solidago canadensis & 7 & 4 & 3 & $7.9 \pm 1.2$ \\
\hline Bromus hordeaceus & 10 different & 11 & 8 & 3 & $6.9 \pm 1.9$ \\
\hline Taraxacum officinale & 7 different & 9 & 1 & 8 & $6.8 \pm 1.9$ \\
\hline Vicia tetrasperma & 7 different & 8 & 3 & 5 & $5.1 \pm 0.8$ \\
\hline Vicia hirsuta & 6 different & 7 & 3 & 4 & $6.7 \pm 1.6$ \\
\hline Vicia sativa ssp. ang. & 6 different & 7 & 2 & 5 & $6.6 \pm 2.4$ \\
\hline Bromus tectorum & 6 different & 7 & 4 & 3 & $5.7 \pm 1.3$ \\
\hline Conyza canadensis & 5 different & 6 & 6 & - & $2.8 \pm 0.4$ \\
\hline Bromus sterilis & 5 different & 6 & 4 & 2 & $8.0 \pm 0.6$ \\
\hline Artemisia vulgaris & 4 differẹt & 6 & 3 & 3 & $6.7 \pm 1.5$ \\
\hline
\end{tabular}


it takes place very early. It is interesting to note that the change to perennials like Artemisia vulgaris is mostly indirect (overlaping), whereas the replacement by other therophytes is mostly made by direct change of dominance. Bromus hordeaceus itself in a number of cases is a follower of Senecio vulgaris; this direct change on the average after 2.4 years. Artemisia vulgaris may be replaced by Poa pratensis ssp. angustifolia or by Solidago canadensis, the two dominant species of the last years mentioned above. In many cases dominances of Vicia species are sandwiched by Bromus hordeaceus and Solidago canadensis. Finally Solidago canadensis can be replaced by Sarothamnus scoparius.

From the figures in Table 11 it is very clear that some transitions are much more common than others. It is, however not possible to construct constant series of dominant species. In fact the series are very variable, and can consist in a small or a greater number of subsequent dominating species. It could be that our data basis is too small; in any case there is no evidence whether and how the first year really acts as a switch leading to the terminal dominance of different species. The mechanism of this differentiation therefore, remains unrevealed.

\section{REFERENCES}

Bakker D., Sina J. Ter Borg. Otzen D.. 1966. Ecological research at the plantecology laboratory. State University. Groningen. 3. On life forms of hapaxants in the Dutch flora. Wentia 15: 13-24.

Bornkamm R., 1984. Experimentell-ökologische Untersuchungen zur Sukzession von ruderalen Pflanzengesellschaften. II. Flora 175: 45-74.

Bornkamm R., 1985a. Vegetation changes in herbaceous communities. In: The population structure of vegetation. White J. (ed.). Junk. Dordrecht. pp. 89-109.

Bornkamm R., 1985b. Veränderungen der Phytomasse und Vegetationsentwicklung. Schriftenr. Vegetationskunde (Bonn-Bad Godesberg) 16: 112-152.

Bornkamm R.. Hennig U.. 1980. Zur Sukzession von Ruderalgesellschaften auf verschiedenen Böden. Phytocoenosis (Warszawa-Białowieża) 7: 129-150.

Bornkamm R.. Hennig U.. 1982. Experimentell-ökologische Untersuchungen zur Sukzession von ruderalen Pflanzengesellschaften. I. Flora 172: 267-316.

Dahl E., Hadač E.. 1941. Strandgesellschaften der Insel Ostoy im Oslofiord. Nytt Mag. Naturv. 82: 251-312.

Griffioen H., 1980. Trifolium arvense L. als winterannual. Gorteria 10: 57.

Grime J.P., 1979. Plant strategies and vegetation processes. J. Wiley. Chichester-New York-Brisbane-Toronto.

Grime J.P., Mason G.. Curtis A. U.. Rodman J., Band S. R.. Mowforth M. A. G. Neal A. M.. Shaw S. 1981. A comparative study of germination characteristics in a local flora. J. Ecol. 69: 1017-1059.

Hulbert L. C.. 1955. Ecological studies of Bromus tectorum and other annual bromegrasses. Ecol. Monogr. 25: 181-213.

Klapp E.. 1954. Wiesen und Weiden. Parey. Berlin-Hamburg. 
Lauer E., 1953. Über die Keimtemperatur von Ackerunkräutern und deren Einflu $\beta$ auf die Zusammensetzung von Unkrautgesellschaften. Flora 140: 551-595.

Oberdorfer E., 1979. Pflanzensoziologische Exkursionsflora. Ulmer. Stuttgart.

Schmidt W., 1981. Ungestörte und gelenkte Sukzession auf Brachäckern. Scripta Geobot. 15: 1-199.

Sissingh G., 1952. Ethologische Synoecologie van enkele onkruid-associaties in Nederland. Mededel. Landbouwhog. Wageningen 52: 167-206.

Tüxen J., 1958. Stufen, Standorte und Entwicklung von Hackfrucht- und Garten-Unkrautgesellschaften und deren Bedeutung für Ur- und Siedlungsgeschichte. Angew. Pflanzensoz. 16: 1-164.

\section{Sukcesja roślinności ruderalnej na stanowiskach zakladanych $w$ różnych porach roku}

\section{Streszczenie}

Prowadzono doświadczenia nad sukcesią roślinności ruderalnej na poletkach o powierzchni $1 \mathrm{~m}^{2}$ na trzech rodzajach gleb $(\mathrm{S}=$ piasek, $\mathrm{SCL}=$ mułowe iły gliniaste, $\mathrm{CL}=$ glina ilasta $)$. Poletka założono w różnych porach roku (od 18.06.1969 do 1.04.1971) i następnie roślinność pozostawiono bez ingerencji przez 9 lat. Największą zmienność składu florystycznego i pokrycia zaobserwowano w zależności od podłoża. Wyraźne różnice sezonowe stwierdzono tylko w dwóch pierwszych latach. Na piasku. w pierwszym roku. rośliny ıednoroczne Comyza canadensis dobrze rozwijały się na poletkach. które założono wiosną, natomiast słabo - na poletkach letnich i jesiennych. W drugim roku roślina zmniejszyła swói udział na poletkach wiosennych, natomiast zwiększyła - na letnich i jesiennych. To samo zjawisko obserwowano dla innego gatunku jednorocznego Sonchus asper, rozwijającego się na CL. Natomiast na SCL, Senecio vulgaris, należący do grupy therophyta epeteia (rośliny zimuiące na siedliskach letnich), dobrze rozwinął się na obu, tzn. na wiosennych $i$ letnich poletkach i wykazał zwiększony udział w drugim roku jedynie na poletkach jesiennych. W następnych latach na poletkach doświadczalnych, które założono wcześniej, dominowały głównie Poa pratensis ssp. angustifolia lub Quercus rubra, podczas gdy poletka założone w późniejszei porze roku były zdominowane przez Solidago canadensis i Artemisia vulgaris. Analiza przypadków pośrednich między roślinami subdominującymi wykazała dużą zmienność następczą w pojawach. ale żadne gatunki nie następowały jedne po drugich $w$ określonych seriach. Pozostaje więc nadal niejasne w jaki sposób zróżnicowanie między ostatecznymi dominantami ma związek z porą roku, w której założono poletka. 